\title{
Was the Seventeenth-Century Commonwealth an Anomaly among Other European States?
}

Back in 1973 Andrzej Wyczański depicted a Poland whose economy and institutional, social and cultural structures did not differ greatly from those of other European countries in the sixteenth century. ${ }^{1}$ Without discussing whether the picture he presented is not too optimistic and - for example - whether the urbanization of Poland really matched that of the West, it should be stated that a similar comparison is all but inconceivable for the following century. It seems unfeasible to set the seventeenth-century Polish nobles' state alongside European absolute monarchies, especially if we were to attempt to collate the forms of government and the directions of their evolution. Wyczański could still try to show similarities between the principles according to which the organs of state authority and the representative bodies of the estates functioned in Poland, England and Spain. ${ }^{2}$ Historians studying the seventeenth century would have to acknowledge - given the current state of research - such an idea as absurd, particularly if they wished to concentrate on similarities which were essential to the functioning of the state and not merely on formal analogies.

For in essence, however different their convictions and doctrines, both Polish historians and scholars from other countries concur to an astonishing degree regarding the specific character of Polish statehood in early modern Europe. This concurrence principally concerns the affirmation of an ever widening gulf between Western European monarchies

1 A. Wyczański, Polska w Europie XVI stulecia, Warsaw, 1973.

2 Ibid., esp. pp. 116-83. 
- which were displaying ever more absolutist proclivities, liquidating the significance of the estates' representative institutions and centralizing executive power - and the Polish state. In the latter, both parliament and the institutions of state power succumbed, if not to complete degeneration, then at least to a far-reaching process of decline.

What has been lost in this comparison is that both the internal transformations of the nobles' state for Polish historians, and the advances of absolutism in the West for scholars of other countries, have not been regarded as a completely obvious question and accepted without serious discussion. This mutual failure to investigate the complexity of both phenomena has effectively resulted in a rather comfortable situation, in which Polish historians confront the transformations of their own country with a fairly uniform image of absolutism. On the other hand for historians from other countries the Polish case is the very image, in essence repeated after Rousseau and Montesquieu, of an anomaly.

Let us for a moment examine the portrayal of early modern absolutism in syntheses written by Polish historians. Józef Andrzej Gierowski, for example, states that absolutism

usually manifests itself at a certain level of development of economic life, notably in the period of the formation of a centralized internal market and the aggravation of class conflicts. In other words, absolutism is a response to such a form of social and economic development in which the predominance of the nobility is preserved in order to secure the strengthening of the position of the monarch against a threat from other estates. Because of this changes made in the sectors of industry, trade and agriculture, necessary for the interest of the state, are implemented under the control of the ruling class. ${ }^{3}$

In turn, Zbigniew Wójcik writes that the building of absolutism

occurs so often on a European scale, that it can be considered the rule for certain stage of historical development. Only in those places where the monarch and the middle nobility were able to conclude an alliance, serving on the one hand the crushing of centrifugal aristocratic opposition, and on the other action against anti-feudal movements and popular uprisings, were major crises avoided, and was the monarchy able to strengthen itself and extend its lifespan, enabling kings to reach for utterly unfettered power. ${ }^{4}$

3 J. A. Gierowski, 'Rzeczpospolita szlachecka wobec absolutystycznej Europy', in Pamiętnik X Powszechnego Zjazdu Historyków Polskich w Lublinie, Warsaw, 1971, p. 102.

4 Z. Wójcik, Historia powszechna, XVI-XVII wiek, Warsaw, 1968, p. 361. 
Other authors of historical syntheses take a similar stance, perhaps stressing to a greater extent the role in the development of absolutism of the bourgeoisie/Bürgerstand - which was, in the opinion of Jerzy Topolski,

the factor that enabled monarchs to expand absolute power, although at the same time it [the bourgeoisie] had to reconcile itself with the limitation of many of its privileges. ${ }^{5}$

These views expressed by Polish historians can easily be criticized for their schematic character; it is probably for this reason that they are wrapped by their authors in numerous reservations, which cannot be detailed here. This is not in any case a criticism of the authors, because synthetic approaches perforce prevent the presentation of the full complexity of the problems in question. And the problem of absolutism is among the most contested in current historiography. Absolutism has been presented as a structure of state organization whose consequence was the acceleration of the state's economic development, but also a system which acted as a brake on such growth. It supposedly arose in the interest of the entrepreneurial strata of the third estate, enabling the development of bourgeois structures, or else it was a system strengthening the position of the feudal stratum, obstructing the advance of the bourgeoisie. It would be possible to cite many more examples of such mutually exclusive, yet nonetheless scholarly judgments. ${ }^{6}$ Historians who are unable to deal with these irreconcilable contradictions often seek the causes of centralized state power and the rise of absolute monarchies in other phenomena, such as war. ${ }^{7}$

Similar tendencies can be observed for the interpretation of the specificity of the development of the Polish state. Seventeenth-century Poland appears as a deformation of the earlier system of nobles' democracy, dominated by magnate côteries, a construction without any real counterpart among other European states. Most of the authors of synthetic works on the development of early modern states hold to this

5 Dzieje Polski, ed. by J. Topolski, Warsaw, 1976, pp. 256-57.

6 Perry Anderson reviews the discussion on absolutism in his The Lineages of the Absolutist State, London, 1974, cited here after the Italian edition (Lo stato assoluto, Milan, 1980), pp. 17-56, 179-214.

7 Cf. for example, G. Parker, The Military Revolution. Military Innovation and the Rise of the West 1500-1800, Cambridge, 1980. 
opinion. ${ }^{8}$ For Polish scholars this problem is obviously more complex, and the causes and evaluation of the constitutional transformations of the Commonwealth are not - and probably will never be - regarded as unambiguous. Historians are inclined to date the beginning of oligarchy and its negative consequences between the beginning and the end of the seventeenth century. For some scholars oligarchy is a stage in the development of nobles' democracy, ${ }^{9}$ while for others it is its perversion, ${ }^{10}$ and for still others it is a meaningless term that only induces error. ${ }^{11}$

The present text does not aim either to present the specificity of the development of the seventeenth-century Commonwealth of nobles or to provide a definitive explanation of the characteristics of an absolute state; still less does it attempt to evaluate the judgments made by historians to date. The author intends to present a hypothesis which suggests the possibility of a rather different reading of the place of Polish statehood in the European context and to point to the existence of other factors which determined the development of constitutional structures in the early modern period.

In one of the most recent syntheses of European history the author, summarizing the events in seventeenth-century England which led to the fall of the monarchy, states that - perhaps - if the concessions or even capitulation of Charles I had occurred earlier, the English state would had transformed itself into another oligarchic construction: managed by a monarch, yet a republican 'half-Poland - half-Venice'. ${ }^{12}$ This statement, although doubtless difficult for some historians to accept, is within the bounds of probability and without doubt will find its adherents. A few decades ago nobody would have treated such a judgment seriously; indeed, probably no historian would have been willing to express it. Little of this change can be ascribed to the progress which has taken place in historical scholarship. It is, to a far greater degree, the effect of the different kind of questions which are asked of the past by Europeans living at the end of the twentieth century.

I believe that the situation presented above can also be applied to the topic of this article, the position of Poland in the early modern era. It is

8 R. Mousnier, La Monarchie absolue en Europe du Ve siècle à nos jours, Paris, 1982, pp. 137-38. Anderson, op. cit., pp. 253-70.

9 Topolski, op. cit., s. 284.

10 J. Maciszewski, Szlachta polska i jej państwo, Warsaw, 1986, p. 12.

11 A. Kersten, Hieronim Radziejowski. Studium władzy i opozycji, Warsaw, 1988, pp. $399 \mathrm{ff}$.

12 K. Pomian, Europa i jej narody, Warsaw, 1992, p. 111. 
probably unnecessary to relate in detail the discussion of the specificity of the development of the nobles' state. Its significance, especially in the context of the later fall of the Commonwealth, is obvious to every historian. I shall therefore confine myself to pointing out the conclusions which most frequently occur and those which are the most essential for my reflections. The dominant characteristic of the evaluations of the Commonwealth of nobles is a profoundly negative balance sheet of its achievements. Only sometimes is this verdict sweetened by statements about undoubted positives, such as the phenomenon of Polish religious toleration and the participation in government by the nobility - a wider section of society than elsewhere, as it constituted over 10 per cent of the whole. The influence of this last factor on the rising level of political culture among the citizens is also emphasized. ${ }^{13}$ It may be doubted whether this strongly evaluative and often emotive character of historians' judgments is wholly justified. In any case we may state that in this discussion the specific characteristics of the Polish case are given prominence, and that it is possible to detect an all too obvious nostalgia among Polish historians for an absolute power that never formed in our country. ${ }^{14}$

When considering the causes of the lack of this centralized form of government historians have drawn attention to the following factors:

1) The lack of a strong bourgeoisie which, according to some authors, was the necessary pillar of every absolute state.

2) The loss by the middle nobility of their position as political actors, which was decisive for the effective functioning of the Polish state.

3) The growth of and acquisition of a dominant position in the state by the stratum of a magnate oligarchy which minimalised the chances of development of a significant centre of royal power.

I present these characteristics in a necessarily simplified form, because the explanation of problems such as the origins of magnate oligarchy, or the chances, either of survival for the middle nobility, or the introduction of absolutism in Poland, would require a significantly larger study.

Polish historians have only found phenomena similar to the transformations occurring the Commonwealth exceptionally rarely. However we should note the enormous excitement generated among Polish historians

13 Cf. for example, Topolski, op. cit., p. 258.

14 Beginning with Adam Naruszewicz in the late eighteenth century, through Michał Bobrzyński in the late nineteenth, Władysław Konopczyński and Władysław Czapliński in the early and mid-twentieth, until the recent generalizations of Henryk Samsonowicz and Jerzy Topolski. 
by the analogy discerned by Władysław Czapliński between the Danish and Polish oligarchic systems, as well as that author's thesis on the chances for a Polish absolutism under Sigismund III Vasa. ${ }^{15}$ Adam Kersten continued Czapliński's attempts to demythologize the system of magnate oligarchy and present the political system in the seventeenth-century Commonwealth as a process of continuous struggle for power between the political elites. For the eighteenth century Jacek Staszewski has pointed to the significantly less extreme character of the differences between the political systems of Saxony and Poland. ${ }^{16}$ It must however be stated that while the efforts of these scholars rather tended to diminish the contrasts between early modern Poland and Europe, the authors themselves did not come close to abandoning the assumption that the Commonwealth's form of government was exceptional.

As mentioned above, the judgments of Western European historians on the particular character of the Polish case are inclined to emphasize the different trajectory followed by the Polish form of government. In this case, however, the situation is easily explicable, given that these historians are in most cases dependent on translations of Polish works, which are few in number. It is not at all strange that the synthetic arguments of Roland Mousnier and Perry Anderson repeat those of Władysław Konopczyński, Oskar Halecki, Aleksander Jabłonowski, Bogusław Leśnodorski and Paweł Skwarczyński. ${ }^{17}$

I believe that the above mentioned characteristics which determined the form of government of the Commonwealth of nobles, and which were decisive for the failure of structures of an absolute state to form, were not exclusively Polish phenomena. They also occurred in countries about which one could certainly not speak about the lack of centralized state power. A book which - in my opinion - should become a genuine turning point in the internationalization of the problem of the Polish state is the work of Antoni Mączak Rzadzacy i rzadzeni [Rulers and ruled].${ }^{18}$ First, because the author, without resigning from the traditional

15 W. Czapliński, 'Rządy oligarchii w Polsce nowożytnej', in idem, O Polsce siedemnastowiecznej. Problemy i sprawy, Warsaw, 1966, pp. 130-63.

16 A. Kersten, 'Problemy władzy w Rzeczypospolitej czasu Wazów', in O naprawę Rzeczypospolitej XVII-XVIII w., Warsaw, 1965, pp. 23-36; idem, Hieronim Radziejowski..., op. cit., pp. 597-602.

17 Anderson, op. cit., pp. $253 \mathrm{f}$.

18 A. Mączak, Rządzący i rządzeni. Władza i społeczeństwo w Europie wczesnonowożytnej, Warsaw, 1986. 
formula of comparing particular characteristics of various state structures, also deals with the social context of systems of power, the problem of its relations with elites and the growing phenomenon of 'professionalization' among the 'rulers'. Second, the significance of the author's approach arises from the process he sketches of the transformation in the early modern period from the dualistic forms of the Ständestaat to more centralized forms. In Antoni Mączak’s approach the centralized structure of power in a state is not, however, the universal motor of development, but rather a general tendency of the absolutist era, in which the most characteristic phenomenon is a continual oscillation of state systems between oligarchic and absolutist forms of power. In his assessment of the place of the Commonwealth in these transformations the author inclines towards the affirmation of its exceptional nature, stating that in the case of Poland a certain model of the state was taken to its conclusion, a model that was by no means exceptional at the end of the middle ages, in conditions of the weak development of a monetary economy with all of its social consequences'. ${ }^{19}$ Despite similarities between certain institutions and similar behaviour among the social elites, in Antoni Mączak's interpretation Poland remains an extremely original phenomenon.

Mączak's book is not a finished thesis, but above all a study that overturns certain stereotypes applied in the analysis of early modern statehood and facilitating - to a rare degree - the anatomy of systems of power and of the elites which participate in them. In his conclusion the author attributes particular significance in the evolution of systems of power to what he calls the connectedness or separateness of three types of early modern elite: based on property, prestige and power. He states that the more these groups coalesce, the lower the chances of centralizing power, whereas the more separate these elites are, the greater the strength of dynamic changes occurring in the state. ${ }^{20}$

This very attractive hypothesis, which has not been noted by the book's reviewers, maintains (in the author's own interpretation) the constitutional specificity of the Commonwealth. It seems, however, that Mączak's proposal also furnishes equally strong arguments for proposing a model for the development of the state in the seventeenth century, which would permit the placing of Poland in the general logic of transformations and not its treatment merely as a particular destination for the Ständestaat.

19 Ibid., p. 278.

20 Ibid., pp. $251 \mathrm{f}$. 
My hypothesis regarding the development of the early modern state and society, far from final precision and based on my research on the evolution of Northern Italian society, may be formulated as follows: ${ }^{21}$

1) The process of development in early modern Europe, especially during the seventeenth century, was predominantly shaped by the extent of the surplus in goods and money creamed off almost exclusively by the noble and aristocratic stratum and by the way in which that surplus was spent. Understood in this way, the crucial transformations were those that took place in the elites of property, prestige and power, and not those transforming Ständestaaten into centralized monarchies. This is a distinction of particular importance for my reflections, given that the main arguments for my hypothesis are supplied by transformations in northern Italy - territory where would be difficult to find a typical Ständestaat, but which led the way in creating the theory and practice of absolute forms of government. ${ }^{22}$

2) The process of development of consumer preferences among social and propertied elites is characteristic for this period. This is usually associated with the transformation either of the knighthood, as in Poland, or with the bourgeoisie - 'betraying' its class interests - into a stratum of landowners. Personally I would now be rather more careful in assigning the landed stratum the role of the principal motor of changes in consumption. In the Italian peninsula the aristocratization of the lifestyle of the patriciate significantly preceded its agrarianization - so the origins of the former phenomenon might be better linked to the extent of the surplus acquired by the elite, to the supply of consumer goods and to other factors shaping the elite lifestyle. This is not all that important in the present context. Above all, it is the consequences of these transformations that are crucial - the rise in Europe of an aristocratic elite linked to landed property or other stable sources of income that do not require so-called entrepreneurship, which was in thrall to various forms of constantly developing and ostentatious consumption. ${ }^{23}$

21 A. Manikowski, Toskańskie przedsiębiorstwo arystokratyczne w XVII wieku. Społeczeństwo elitarnej konsumpcji, Warsaw, 1991, pp. 174-200.

22 On the northern Italian crisis, cf. for example, G. Quazza, La decadenza italiana nella storia europea. Saggi sui Sei-Settacento, Turin, 1971; cf. also: Failed Transitions to Modern Industrial Society: Renaissance Italy and Seventeenth-Century Holland, ed. by F. Krantz and P. M. Hohenberg, Montreal, 1975; Y.-M. Bercé, G. Delille, J.-M. Sallman, and J.-C. Waquet, L'Italie au XVIIe siècle, Paris, 1989, pp. 15-54, 83-118.

23 On the transformations and characteristic development of the European aristocracy see, for example, L. Stone, Family and Fortune: Studies in Aristocratic Finance in the 
3) The further consequence of the evolution of this elite is the process of concentration of property in the hands of an ever smaller group of the 'truly rich', a process whose apogee may be firmly dated to the second half of the seventeenth and the eighteenth century. This growth of a purely aristocratic elite and the absolute dominance of the lifestyle model it promoted is linked to its loss of 'entrepreneurial' behaviour and the resulting development of consumerist outlooks, which are passive in economic terms. Here it is worth noting that despite the generally accepted assumptions, in Italian conditions this aristocratic elite retained in practice the almost exclusive disposal of monetary surpluses without causing (or almost without causing) the expected competition from the Third Estate while practically eliminating the middle strata. This last phenomenon constitutes a significant analogy for the Polish case. ${ }^{24}$

4) Finally there is a question that is fundamental for this problem: this dynamically developing aristocratic elite needed a new state organization, adapted to its needs. Considering its numerical strength, tendency maintain and accentuate the principles of social hierarchization, financial and sometimes even military potential, the only forms of government which it could accept were absolute monarchy and oligarchy. Neither the Ständestaat on the one hand, nor civic republicanism on the other, could represent the actual balance of forces in society, and so neither of these forms of government had any reason to subsist. They were unable to survive, less because of anti-democratic stance of the aristocracy than because they did not offer similar guarantees of a secure and stable state system to those provided by absolutism or some forms of oligarchy.

The problem - or the question - remains: why did an essentially fairly uniform evolution of the aristocratic elite produce such different effects in various European countries? In other words, how did it happen - if the model of social development proposed above has a reasonable degree of probability - that this same process led on the one hand to the monarchy of the Sun King, and on the other to a state as lacking in a significant centre of power as the seventeenth-century Commonwealth? It seems that

Sixteenth and Seventeenth Centuries, Oxford, 1973; idem, The Crisis of the Aristocracy 1558-1641, Oxford, 1965; H.R. Trevor-Roper, 'The Elizabethan Aristocracy: An Anatomy Anatomised', Economic History Review, 2nd series, 3, 1954, pp. 279-98; P. Malanima, I Riccardi di Firenze. Una famiglia e un patrimonio nella Toscana dei Medici, Florence, 1977 or R. B. Litchfield, Emergence of a Bureaucracy: The Florentine Patricians, 1530-1790, Princeton, NJ, 1986.

24 Manikowski, op. cit., pp. 159-73. 
there is no sense in setting two such extreme examples of constitutional development alongside each other, especially given that the spectrum of intermediate forms between them indicates that we are dealing not only with a rule and an exception, but with two variants of the same process. The example of the constitutional evolution of the Apennine Peninsula may be especially instructive. That said, Mączak's diagnosis should be endorsed: 'Absolutism should be treated as a tendency, not as a completed, uniform and internally consistent phenomenon. It has also been noted that the central organs of power - the monarch, his circle and finally the assembled estates - are only the peak of a hierarchically shaped system, usually full of internal contradictions and based, importantly, on a system of property, especially landed property. This is what creates the rich variety of forms of power'. ${ }^{25}$

And yet in the historiographical tradition the essence of the debate on the origins of absolutism is usually reduced to considering whether it was a system defending the interests of the feudal stratum against a Third Estate that sought to storm its positions, or the opposite, whether it was a form of government guaranteeing the advance of the bourgeoisie. I must admit that I have never been an enthusiast for looking at the problem of European absolutism in the categories of a kind of class conflict. This is not because I would question the role of social tensions in the process of social development, but rather because this type of the development of absolutism with an ethos of the 'Third Estate' written into it fits the model of the monarchy of the Valois and the Bourbons, but does not find confirmation across a wide spectrum of other European states. This phenomenon cannot be presented with regard to Spanish absolutism, which is as 'classical' a model as the French. Still less does it apply to the transformations in Northern Italy. Far more convincing is the above vision of absolutism as a certain tendency creating - as I believe - a system answering the needs of aristocratic elites, and the Italian region appears to be a perfect confirmation of this phenomenon.

The sixteenth century brings a fairly general process of transformation for Italian statehoods into monarchical structures of varying degrees of stability and sovereignty. They have all the characteristics assigned to the absolute state - a developing court structure, an expanded bureaucracy inherited from republican systems and adapted to new requirements, state interventionism in the economy, they pursue protectionist policies

25 Mączak, Rządzący..., op. cit., pp. 128-33. 
in defence of luxury crafts, and finally they generate institutions creating and formalizing the existence of the aristocratic elite. The Grand Duchy of Tuscany may be recognized as an example of a model absolute state. ${ }^{26}$

At the same time, however, in the cases of these forms of statehood we can speak only with difficulty about differentiated elites. The elite of property is the same here as the elite of prestige. The aristocracy of blood and titles is also the urban patriciate, or the potential Third Estate, which in practice means the absence of the fundamental - for absolutism source of social tension. While we may speak of the existence of a third kind of elite - that of power - it appears on the territory of the Grand Duchy of Tuscany as a separate social group only the first, 'heroic' period of the creation of the structures of the absolute state, when Cosimo I and Ferdinand I, struggling against the existing opposition, give a part of the power to professional lawyers of foreign extraction, filling the new offices of secretaries and auditors. In the following century however, we see these descendants of the Usimbardis or Vintas well married into the old Florentine aristocracy, taking possession of offices and collecting titles and dignities on an equal basis with the older families. The historians of the late phase of the Medici period, Jean-Claude Waquet and R. Burr Lichtfield, unequivocally aver the ongoing aristocratization of the higher Tuscan offices, which in practice means the taking on by the state's elites of a similar character to the magnate elite in the Commonwealth - which was exceptionally homogeneous. ${ }^{27}$

Analogies with the transformations occurring in the Commonwealth do not end with the example of Tuscany. In seventeenth-century Italy we may observe a process of such a significant increase in propertied wealth among some aristocratic families, that they become possessors of vast property in several Italian states, even without counting clergymen holding numerous bishoprics and linked with their own families by their interests. All this

26 On Tuscany and the directions of its constitutional transformations, cf. in particular, Litchfield, Emergence..., op. cit., esp. pp. 127-262; J.-C. Waquet, Le Grand-Duché de Toscane sous les derniers Médicis, Rome, 1990, pp. 13-137, 491-576; P. Malanima, La decadenza di un'economia cittadina. L'industria di Firenze nei secoli XVI-XVIII, Bologna, 1982; S. Berner, 'The Florentine Patriciate in the Transition from Republic to "Principato" 1530-1609', Studies in Medieval and Renaissance History, 9, 1972, pp. 2-15; F. Diaz, Il Granducato di Toscana. I Medici, Turin, 1976, esp. pp. 231-421. 27 Waquet, Le Grand-Duché..., op. cit., pp. 511-33; R. B. Litchfield, 'Les Investissements commerciaux des patriciens florentins au XVIII siècle', Annales ESC, 24, 1969, pp. 685-721; idem, Emergence..., op. cit., pp. 129-54. 
leads to the emergence of a fairly informal, but nonetheless obvious Italian system of oligarchy, whose centre was the dynamically growing capital of the Papal States. The political significance of Rome per se may be - perhaps - second-rate, but Rome becomes the place where the hierarchy is shaped, not only of ruling Italian dynasts but also of the most powerful part of the aristocracy. The papal court, especially during a vacancy on the Petrine throne, is strongly reminiscent of the situation during a royal election in Poland. This is, after all, the choice of elective absolute monarch, which is always the outcome of internal Italian agreements and rivalries discreetly piloted by the interested capitals of the great powers: Paris, Madrid and to a lesser extent Vienna. If we add that here the classically oligarchical structures of two republics - Venice and Genoa - maintain themselves in an unthreatened condition, then in effect we obtain a picture of Italy that greatly complicates the uniform picture, usually opposed to Poland, of a centralizing Europe, in which the dominant tendencies pointed towards the creation of territorially integrated states. ${ }^{28}$

We may of course judge that Italy was an untypical territory and so treat the peninsula rather like the specific case of Poland. It seems, however, that the phenomenon of the unification and domination of an aristocratic elite, showing understandable tendencies to evolve towards oligarchy, can be found in a larger number of European countries. Bartolomé Bennasar, when he describes Spain during the reigns of Philip IV and Charles II, portrays a fairly unambiguously a state in which the power of the centre becomes ever more of a fiction and the country is ruled and well-nigh plundered by the Mendozas, Giróns and Cordonas acquiring fortunes of which the Lubomirskis or Potockis would not have been ashamed. Similar developments also occur in Sweden, which after the centralization and reforms of 1680 experiences a renaissance of oligarchic structures after $1718 .^{29}$

28 On the specificity of the elective papal monarchy, cf. P. Prodi, Il sovrano pontefice. Un corpo e due anime: la monarchia papale nella prima età moderna, Bologna, 1982; A. Caracciolo and M. Caravale, Lo Stato pontificio da Martino V a Pio IX, Turin, 1978, pp. 139-448. The constitutional transformations of Venice and Genoa are presented by G. Cozzi, Repubblica di Venezia e Stati italiani. Politica e giustizia dal secolo XVI al secolo XVIII, Turin, 1982; and E. Grendi, La Repubblica aristocratica dei Genovesi. Politica, carità e commercio fra Cinque e Seicento, Bologna, 1988.

29 B. Bennassar, Histoire des Espagnols, vol. 1, Paris, 1985, pp. 524-26; M. Roberts, 'On Aristocratic Constitutionalism in Swedish History, 1520-1720', in idem, Essays in Swedish History, London, 1967, pp. 14-55. 
In accepting the assumption made by Mączak of the universality of the absolutist type of changes in Europe as well as the simultaneously existing tendency to restore an oligarchical system, we can state that in such an interpretation the seventeenth-century Commonwealth can be placed in the general convention of constitutional transformations serving the dominant aristocratic elites of property and prestige, and to a considerable degree also of power. Poland is an untypical example, in that during its history not one attempt to concentrate power in the hands of monarch ever succeeded.

It also appears that in interpreting absolutism in this way, we are entitled to treat this system not as a kind of historical necessity, but as a phenomenon, against which the main protagonist of our reflections, the aristocracy, had the right to defend itself. There arises in connection with this the problem of whether the question of the essence of the early modern state should not be reversed, looking rather for the factors which forced the aristocracies of the majority of European countries to resign from its freedoms and which prevented the maintenance of oligarchic power, and in the case of Poland - the circumstances which enabled the magnates successfully to resist absolutism. If my question meets the conditions of rationality, then the answer to it, reached by the comparative analysis of forms of government and elites in many European states, may fundamentally change our judgments of the place of the Commonwealth in early modern Europe.

\section{Translated by Wioletta Pawlikowska-Butterwick and Richard Butterwick-Pawlikowski}

First published as: 'Czy siedemnastowieczna Rzeczpospolita była anomalią wśród innych państw europejskich?’, Odrodzenie i Reformacja w Polsce, 37, 1993, pp. 79-87. 